Revista de Estudios Histórico-Jurídicos

[Sección Derecho Romano]

XXXVI (Valparaíso, Chile, 2014)

[pp. 159 - 187]

\title{
LA PATRIA POTESTAD EN EL DERECHO ROMANO Y EN EL DERECHO ALTOMEDIEVAL VISIGODO
}

[Patria potestas in the Roman Law and in the Late Middle Ages Visigothic Law]

\author{
Guillermo SuÁrez BLÁZQUEZ* \\ Universidad de Vigo, España
}

\section{RESUMEN}

La patria potestas nace como un derecho absoluto, originario y exclusivo de los ciudadanos romanos sobre sus hijos e hijas, que garantizaba la unidad y el gobierno de la familia y la descendencia por vía de varón. Con todo, la extensión de este derecho fue limitándose y sufrió cambios evolutivos en su naturaleza jurídica durante los períodos históricos por los que atravesó la vida de Roma. La caída del Imperio romano de Occidente no supuso su derogación. Por el contrario, este derecho civil personal del pater familias romano se proyectó al derecho del alto medievo del reino visigodo.

Palabras Clave

Patria potestas en el derecho romano Patria potestas en el derecho visigodo.
Abstract

Patria potestas arises as an absolute, primary and exclusive right of Roman citizens over their sons and daughters, which guaranteed the family unity and governance and the paternal line of descent. All in all, the scope of this right became gradually limited and underwent evolutionary changes in its legal nature over the historical periods in Roman life. The fall of the Western Roman Empire did not entail its derogation. On the contrary, this personal civil right of the Roman pater familias was projected onto the law in the Late Middle Ages Visigothic Kingdom.

\section{KEYWORDS}

Patria potestas in Roman Law - Patria potestas in the Visigothic Law.

RECIBIDO el 3 de enero y ACEPTADO el 26 de julio de 2014

* Profesor titular de derecho romano y sistemas jurídicos contemporáneos de la Universidad de Vigo. Correo electrónico: gsuarez@uvigo.es 


\section{ANTECEDENTES DEl DERECHO CIVIL ROMANO}

1. La patria potestad es una institución jurídica originaria del derecho quiritario $^{1}$ civil de Roma. Desde los tiempos primigenios de la ciudad, aquélla fue configurada como un poder jurídico personal, propio y exclusivo de los ciudadanos romanos libres. Según la mitología que nos refiere Tito Livio, existieron diferentes tradiciones orales sobre los orígenes de Roma. Para unos la ciudad fue fundada por Eneas ${ }^{2}$. Las versiones de otros creen en Rómulo ${ }^{3}$ y Remo. Para nosotros un punto relevante de ambas mitologías históricas es que ambas coinciden en sostener que los fundadores de la Ciudad estado fueron precisamente los varones. Sólo los ciudadanos, quirites, tuvieron el poder de fundar las familias y, mediante su unión, la patria. En consecuencia, la familia romana es de uno: el paterfamilias. Y la patria potestad es un poder político de uno: el paterfamilias. La patria potestad romana es originariamente el poder político de los hombres libres, potestas que cierra el paso al gobierno de la cosa pública y de la familia a las mujeres ciudadanas. Estas raíces primigenias de la patria potestad son muy profundas, y perdurarán durante todo el tiempo de la vida de Roma. En este sentido, Gayo, quien nos reporta en sus Institutiones un edicto de Adriano, sostiene que los otros pueblos de la antigüedad no conocieron, o al menos, no practicaron el ejercicio del derecho de la patria potestad: "Item in potestate nostra sunt liberi nostri quos iustis nuptiis procreavimus. Quod ius propium civium Romanorum est, fere enim nulli alii sunt homines qui talem in filios suos habent potestatem, qualem nos habemus, idque divus Hadrianus edicto, quod proposuit de his qui sibi liberisque suis ab eo civitatem Romanam petebant significavit"'.

2. Este derecho es propio de los ciudadanos romanos, pues apenas hay hombres que tengan una tal potestad absoluta sobre sus hijos como la que tenemos nosotros. Sin embargo, una lectura atenta del fragmento de Gayo $(1,5)$ parece indicar que el jurista se distancia, dubitativo, de la afirmación oficial del emperador , pues nos dice que la nación de los gálatas cree que tiene a los hijos bajo la patria potestad de los padres 5 . El jurista reporta además, en otro apartado de $(1,189)$ que por razón jurídica natural -naturali rationi- los otros pueblos y naciones (en ausencia de patria potestad) tienen y ejercen un derecho de tutela que se concede a un tercero sobre los hijos impúberes ("in tutela esse omnium civitatium iure contingit”) ${ }^{6}$. Y, precisamente, en este fragmento Gayo vuelve a confirmar que sólo los ciudadanos romanos tienen a sus hijos bajo la patria potestad, "ut supra diximus, soli cives

\footnotetext{
${ }^{1}$ SeVILla, Isidoro de, Etymologiae V,10: "Quid sit ius Quiritium. [1] Ius Quiritum est proprie Romanorum, quo nulli tenentur nisi Quirites, id est Romani, tamquam de legitimis hereditatibus, de cretionibus, de tutelis, de usucapionibus; quae iura apud alium nullum populum reperiuntur, sed propria sunt, Romanorum et in eosdem solos a constituta".

${ }^{2}$ Liv., Ab urbe cond., I,1.

${ }^{3}$ Ibíd., I, 7.

${ }^{4}$ Gai. 1,$5 ; 1,189$.

${ }^{5}$ Gai. 1,55.

${ }^{6}$ Gai. 1,189.
} 


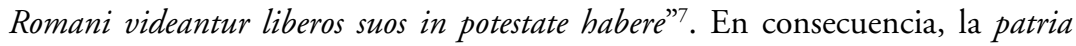
potestas ex iure Quiritium est, tutela gentium.

3. La patria potestad es un medio jurídico de sometimiento del alieni iuris. Por su parte, la tutela es un medio de vigilancia y protección del sui iuris, que se ejerce, precisamente, en ausencia de patria potestad. Y, aunque la afirmación de Gayo nos deja un interrogante sin respuesta sobre la posible existencia de una patria potestad sobre los hijos en la nación de los gálatas, parece muy acertada la opinión de Volterra, quien manifiesta que la patria potestad romana nunca pudo ser ejercida por los extranjeros, ni por los esclavos. Ambas categorías de hombres no gozaron de la ciudadanía romana ${ }^{8}$, tampoco del ius civile.

Por otra parte, como advirtiera Schulz ${ }^{9}$, aunque los juristas romanos fueron reacios a definir los conceptos jurídicos, sin embargo, sí fueron muy proclives a su descripción. Tal vez, por este motivo, no se encuentran en las fuentes jurídicas muchas definiciones del concepto de familia ${ }^{10}$ ni de la patria potestad. En este sentido, por su parte, el jurista Paulo describe sus significados y liga la institución a la noción de potestas: "Potestatis verbo plura significantur; in persona magistratum imperium, in persona liberorum patria potestas, in persona servi dominium"11.

4. Desde otra perspectiva, Gayo (Inst. 1,48) había reportado algunos años antes que Paulo que la patria potestad es un instrumento jurídico que cumple un fin de sometimiento, pues afirmaba que mediante ella las personas "alieno iure subiectae sunt". En línea con este argumento de Gayo, es posible sostener que desde los tiempos primigenios de la ciudad estado, las primeras instituciones jurídicas que cumplieron este cometido, es decir, la creación de un vínculo jurídico de sujeción, nexo, o ligamen jurídico, fueron la patria potestas, la manus y la entrega de los hijos in mancipio (Gai. 1,49). Todas fueron instituciones jurídicas que formaron parte del elenco originario del ius Quiritium arcaico, y otorgaron al pater familias un poder que le permitió someter corporalmente y materialmente a diferentes personas a su derecho y gobierno, de forma permanente (Gayo Inst. 1,48). Tres nexos o vínculos jurídicos del paterfamilias que cumplieron finalidades diferentes y determinaron, sin duda, la condición jurídica de las personas sometidas. En esta dirección se debe Antonio Fernández de Buján cree que "el poder del paterfamilias tenía carácter unitario" ${ }^{2}$. En consecuencia, se puede afirmar que desde los primeros siglos de la vida de Roma, y en relación a la patria potestad, ésta fue concebida como un poder (potestas) jurídico civil que el pater-familias ejerció sobre los hijos. La manus, institución jurídica que parece tener tanto antecedentes indo-europeos (man-, ma) como del sánscrito (daman), (según Pietro Bonfante, nombre equiva-

\footnotetext{
${ }^{7}$ Gai. 1,189 .
}

${ }^{8}$ Volterra, Edoardo, Instituciones de derecho privado romano (traducción de J. Daza Martínez, Madrid, Civitas, 1988), p. 110.

${ }^{9}$ Schulz Fritz, Principios del derecho romano (traducción al castellano, 2a edición, Madrid, Civitas, 2000), pp. 65-69.

${ }^{10}$ Volterra, Edoardo, s. v. "Famiglia (dir. rom)", en Enciclopedia del Diritto (Varese, Giuffré, 1967), XVI, p. 724.

${ }^{11}$ D. $50,16,215$.

${ }^{12}$ Fernández de Buján, Antonio, Derecho privado romano (4 $4^{\mathrm{a}}$ edición, Madrid, Iustel, 2011), p. 268. 
lente a doméstico ${ }^{13}$ ) es un poder que ejerce el pater sobre los hijos en régimen de monopolio, en el ámbito de la familia. El paterfamilias crea su familia (= grupo de sometidos) mediante un matrimonio exogámico de pareja. Este matrimonio arcaico es acompañado por la conventio in manu. Esta institución jurídica se lleva a cabo bien mediante confarreatio, bien mediante coemptio, bien mediante $u^{14} \boldsymbol{s}^{14}$. Estos modos generan la adquisición de la manus maritalis sobre la mujer casada. Nexo que une al paterfamilias con su esposa: uxor in manu. Según Gelio $(18,6,9)$ ésta adquiere el título de mater familias e ingresa en la familia bajo el poder del marido, o del paterfamilias bajo el que se encuentre sometido su marido: " $m a$ trem autem familias appellatam esse eam solam, quae in mariti manu mancipioque aut in eius, in cuius maritus manu mancipioque esset". Sin embargo, al decir de la jurisprudencia clásica, la mujer se encuentra sometida a aquél como si fuera una hija (loco filiae), o como una nieta (loco neptis). Es decir, este vínculo supone para la mujer el goce de un plano jurídico cualitativo diferente al de los hijos. Por su parte, el pater familias puede finalizar este poder mediante un acto jurídico dirigido a la disolución de la conventio in manus, bien con una difarreatio, bien mediante el recurso a una remancipatio, bien mediante el cese de la convivencia durante tres noches consecutivas (usurpatio trinoctii).

5. En este contexto histórico y jurídico, se debe situar la tesis de Volterra, quien advirtió que desde los primeros tiempos de Roma, la institución de la patria potestad se ligó, sin duda, a la ciudadanía nacional romana y al matrimonio, pues este siempre estuvo destinado a la fundación del grupo familiar. El clan familiar romano es una unidad jurídica autónoma (ex iure Quiritium) que es gobernada única y exclusivamente por el paterfamilias. Los hijos y las hijas, que nacen de justas nupcias, adquieren el título jurídico civil bien de filius familias, bien de filiafamilias y quedan vinculados y unidos, en un régimen de filiación civil (adgnatio) al poder soberano del paterfamilias. De acuerdo con esta tesis, se puede afirmar que la familia romana arcaica es una institución jurídica del vetus ius civile que forma parte de la civitas como Estado. Esta familia arcaica quiritaria se ancla en el matrimonio y se cohesiona mediante la espina dorsal de la patria potestas. Ésta, a su vez, se conforma por tres nervios jurídicos civiles: patriarcal, patrilineal y político.

a) El adjetivo "patriarcal" significa que sólo los patres (sui iuris) sin ascendientes masculinos pueden ser los jefes civiles y religiosos de la familia. La familia es una institución de y para los varones, patres, quirites. El derecho de Roma nunca admitió la familia matriarcal ${ }^{15}$. La patria potestad romana es un poder jurídico viril. El paterfamilias es el titular del gobierno de todos los nexos que someten a los miembros del grupo familiar. Todos los componentes de la familia están sometidos (alieni iuris) al poder del varón, ciudadano romano, sui iuris. También, el marido somete y subyuga a su esposa, uxor in manu. Ésta ocupa la posición de

${ }^{13}$ Bonfante, Pietro, Corso di diritto romano, II: La proprietà, 1 (Milano, Giuffre, 1966), p. 253. Voz: “manus, us”, en A Latin Dictionary Lewis and Short (reimpresión, Oxford, 1989), p. 1.111 .

${ }^{14}$ Gai. 1,110 .

${ }^{15}$ Volterra, E., cit. (n. 10), p. 728. 
hija (loco filiae) si su esposo ejerce la patria potestad, o de nieta (loco neptis) si es el padre de su marido el titular de aquella. En este sentido, el jurista Gayo sostiene que la mujer y toda su línea descendente femenina legítima son principio y fin de su familia. En consecuencia, la mujer no tiene competencia para ser titular del poderío civil de la patria potestad, ni puede fundar su propio grupo familiar. El gobierno de la familia y el ejercicio de la patria potestad son facultades jurídicas viriles. Esta mentalidad está muy presente en la jurisprudencia clásica. Así, al decir de Gayo, en la denominación de familia se comprende al princeps familiae ${ }^{16}$. La familia es un grupo civil, religioso y económico que gobierna un primero, varón. El padre de familia es el eje protector del grupo, y todos sus miembros permanecían unidos, sometidos y vigilados permanentemente por aquel.

b) El vínculo es patrilineal porque a la muerte del padre, la patria potestad se transmite en línea descendente de ciudadano romano a ciudadano romano, de varón a varón, nacido de justas nupcias, o adoptado. El padre de familia gobierna y une el clan mediante la patria potestad. La patria potestad, como poder descendente masculino de cohesión del grupo, es perceptible en las diferentes atribuciones de las que goza el paterfamilias, pues, por ejemplos, es libre de retener y subyugar a un nieto bajo su patria potestad y, con seguridad, desde el año 450 a. C. merced a la lex XII Tabularum (Tab. IV) puede disolver el poder y expulsar del grupo familiar a su hijo (emancipatio) (quien en virtud de ésta se hace sui iuris, pero pierde el título de filius familias). La intensidad y el valor de la patria potestad no son uniformes. Esta tesis es deducible de la legislación decenviral. Si el paterfamilias quiere disolver el poder de su patria potestas, que ejerce sobre los hijos varones, tiene que realizar tres mancipationes. Sin embargo, si el paterfamilias desea renunciar a su derecho y disolver la patriapotestas que ejerce sobre las hijas o descendientes en segundo grado, nietos, nietas, biznietos y biznietas es suficiente una mancipatio ${ }^{17}$. Y este proceso de disolución es idéntico si el paterfamilias quiere disolver la patria potestad para entregar a sus hijos en adopción (sub potestate) a un nuevo paterfamilias ${ }^{18}$. Es evidente que el valor de la patria potestad no es idéntico para todos los sometidos. Tal vez la razón es que los hijos son continuadores de la patria potestad y de la ciudadanía romana. La mujer abandona y se hacen jurídicamente extraña a su familia cuando ingresa como uxor in manus mariti (loco filiae, loco neptis) en otro grupo familiar. Este carácter patrilineal por línea de varón de la patria potestad se mantiene en vigor en la etapa clásica, y es puesto de relieve por Gayo: "itaque si moriente avo pater eorum et vivit et in potestate patris fuerit, tunc post obitum avi in patris sui potestate funt; si vero is, quo tempore avus moritur, aut iam mortuus est aut exiit de potestate patris, tunc hi quia in potestatem eius cadere non possunt, sui iuris funt"19.

c) La patria potestas es política y agnaticia, porque las facultades y poderes del pater nacen de aquella. El sometimiento a la patria potestad de los miembros de la

${ }^{16}$ D. $50,16,196$.

${ }^{17}$ Gai. 1,132 .

${ }^{18}$ Gai. 1,134. La mujer in manu sale de la manus del marido con una sola mancipatio (Gai. 1,137).

${ }^{19}$ Gai. 1,127. 
familia, por nacimiento en justas nupcias ("item in potestate nostra sunt liberi nostri quos iustis nuptiis procreavimus"20) adopción ("non solum tamen naturales liberi secundum ea quae diximus, in potestate nostra sunt, verum et hi quos adoptamus" ${ }^{21}$ ) y arrogación ${ }^{22}$, hace surgir la filiación agnaticia y califica a los hijos e hijas como filiifamilias y filiasfamilias. Estos títulos constituyen acreditaciones jurídicas civiles en favor de los alieni iuri sub potestate patris, quienes, con la muerte de éste, son nombrados, ex lege iuris civilis, heredes sui" ${ }^{23}$. El sometimiento ("alieno iure subiectae sub potestate patris”) es civil y político, y perpetúa los vínculos agnaticios de la familia. Los sometidos sub potestate patris siguen la condición jurídica del padre: son ciudadanos romanos. En consecuencia, los hijos adquieren mediante la filiación jurídica que surge de la patria potestad sus tria nomina: praenomen, nomen, y cognomem. Praenomen que adquieren de su paterfamilias y que los define como ciudadanos, ingenuos y miembros de una familia proprio iure ${ }^{24}$. El nomen acredita jurídicamente a los hijos (adoptivos y naturales) como miembros de un clan o tronco común familiar gentilicio (familia communi iure). Grupo gentilicio que pertenece a la ciudad de Roma (la antigüedad del nomen es reportada incluso por inscripciones epigráficas del siglo VII a. C. ${ }^{25}$ ). Por último, el cognomen es un apodo o singularidad que, dentro del grupo familiar gentilicio, designa a los miembros de la familia más estricta, familia propio iure. A la muerte del padre, la hereditas perpetúa la continuidad de la estirpe gentilicia y de la familia agnaticia. Los vínculos cognaticios son extraños al ius quiritium y a la patria potestad, $\mathrm{y}$, en consecuencia, a la familia y a su gobierno. Los hijos que son liberados de la patria potestas y expulsados de la familia agnaticia pierden su condición de filius familias y filia familias y son sui iuris, emancipados de derecho propio, consanguíneos de sus hermanos que permanecen bajo patria potestad. Cabe preguntarse, ¿qué derecho propio? En origen, creemos que es muy probable que la liberación de los hijos por emancipatio significa el cambio de status por un proceso de expulsión y disolución del poder de la patria potestas, (capitis deminutio ${ }^{26}$ ) y, en consecuencia, de extrañamiento del hijo o hija (extranei) de la familia, Incluso, si el emancipado llega a suceder al padre por testamento es heredero extraño ${ }^{27}$. Con todo, desde los tiempos primigenios, los vínculos de consanguinidad se tienen en cuenta por el derecho para evitar matrimonios incestuosos. Estas uniones fueron calificadas por la jurisprudencia pontifical como actos contrarios a la religión, nefariae ${ }^{28}, \mathrm{y}$ al ius civile, matrimonio iniustum. Además, con el paso de los siglos, la familia

\footnotetext{
${ }^{20}$ Gai. 1,55 .

${ }^{21}$ Gai. 1,97-99.

${ }^{22}$ Gell., V,19,9: "Quam si ex eo patre matreque eius natus esset, utique ei vitae necisque in eum potestas siet".

${ }^{23} \mathrm{Tab} . \mathrm{V}$.

${ }^{24}$ D. $50,16,195,2$.

${ }^{25}$ López Barja de Quiroga, Pedro - Lomas Salmonte, Francisco Javier, Historia de Roma, (Madrid, Akal, 2004), pp. 40-41.

${ }^{26}$ Gai. 1,162 .

${ }^{27}$ Gai. 2,161.

${ }^{28}$ GAUdEMET, Jean, El matrimonio en Occidente (traducción al castellano Madrid, Taurus, 1993), pp. 43-44.
} 
cognaticia también entrará en el punto de mira del derecho de sucesiones, por la intervención jurisdiccional de los pretores, de la jurisprudencia y del tribunal de los centumiviri. Por su parte, Valerio Máximo ${ }^{29}$, todavía reporta, en los comienzos del Principado, que los vínculos cognaticios pertenecen al orden natural, no al derecho civil.

\section{Naturaleza jurídica polivalente DE la “patria potestas”}

Desde los tiempos iniciales, la patria potestas del paterfamilias fue un poder jurídico ex iure Quiritium) y polivalente, que cumplía diversas finalidades: $i$ ) Personal, de naturaleza jurídica privada, pues se ejerce, sobre los hijos, en el estricto ámbito de la familia y de la domus; ii) Personal, de naturaleza jurídica pública, porque produce efectos jurídicos relacionados con la adquisición de la ciudadanía romana (vale decir nacionalidad) que repercuten en la vida y en la ordenación de colectividad; iii) Personal, de naturaleza jurisdiccional, porque el paterfamilias puede enjuiciar actos ilícitos penales y crímenes cometidos por los hijos; iv) Personal, de naturaleza coercitiva, porque el paterfamilias puede imponer penas a todos los sometidos; $v$ ) Personal, de naturaleza jurídica religiosa, porque habilita a la dirección de los cultos religiosos y de los dioses domésticos ${ }^{30} ; v i$ ) Personal, de naturaleza económica ${ }^{31}$, absorbente, calificada de inhumana por Justiniano (" quod nobis inhumanum visum est" ${ }^{32}$ ), pues todas las adquisiciones de los sometidos sub potestate pasan ipso iure al patrimonio del paterfamilias.

El paterfamilias dirige y gobierna la domus de la misma forma que los magistrados y el emperador gobiernan la República. El concepto de poder político es subrayado y puesto en valor por Paulo, pues si aceptamos los significados de potestas que este jurista nos ha reportado, a partir de la República, el equivalente de la potestas como imperium, o poder que ejercen los magistrados sobre los ciudadanos, es la patria potestas, o poder de gobierno que ejerce el paterfamilias sobre los hijos ${ }^{33}$. En este sentido, al decir de Juan María de La Torre, "la polis (ciudad) no es más que una extensión de la domus. De paterfamilias deriva el princeps o imperator. Y evidentemente, de la economía familiar, la oikonomía, se origina la política, la politeia" ${ }^{34}$.

\section{EVOLUCIÓN JURÍDICA DE LA PATRIA POTESTAD ROMANA}

La familia romana arcaica es aglutinada por la potestas del paterfamilias. En origen, esta es irrenunciable (sólo finaliza con la muerte y la capitis deminutio maxima

\footnotetext{
${ }^{29}$ VAL. MAX. VI,7,2.

${ }^{30}$ Fustel de Coulanges, Numa Denis, La cité antique, (Paris, 1903).

${ }^{31}$ Arangio Ruiz, Vincenzo, Le genti e le città, en Ann. Messina, 1913-1914, pp. 58 ss.; VOLTERra Edoardo, L'opera scientifica di Arangio Ruiz, en Archivio Giuridico, 170 (1966), pp. 8-10.

${ }^{32}$ Inst. 2,9,1.

${ }^{33}$ D. $50,16,215$.

${ }^{34}$ DE LA TORRE, Juan María, Literatura cristiana antigua, entornos y contenidos, I: Desde su origen a la formación de la gran Iglesia (Zamora, Monte Casino, 2003), p. 72.
} 
del pater familias) y cumple una misión de sometimiento corporal permanente de los hijos e hijas ${ }^{35}$. Esta naturaleza perpetua de la patria potestad evoluciona en el plano jurídico civil con la promulgación de la Ley de las XII Tablas (450 a d. C.) norma que permite al paterfamilias renunciar a su derecho, suo iure eas personas dimittere ${ }^{36}$, disolver, voluntariamente ${ }^{37}$ y jurídicamente (emancipatio) su la patria potestad y, de este modo, liberar, iure liberentur ${ }^{38}$, a los alieni iuris ${ }^{39}$ que hubiesen sido legitimados previamente por nacimiento, adopción o adrogación. En esta dirección, es posible que la emancipación naciese como un derecho del paterfamilias. En este sentido, acertadamente, apunta Gaudemet que "la mayoría de edad en Roma nunca existió" ${ }^{40}$, es decir, una edad legal de disolución forzosa del poder de la patria potestad.

Por otra parte, la naturaleza, el alcance y las facultades de este poder, que tanto enorgullece a los romanos (no en vano crea la nacionalidad que es la ciudadanía y, por ende, a Roma como ciudad estado, entendida como comunidad jurídica y políticamente organizada) no fueron siempre uniformes, pues sufrieron profundas transformaciones a lo largo de las distintas etapas históricas por las que atravesó la vida de Roma. Con el paso del tiempo, la propia concepción de la familia agnaticia arcaica sufre erosiones en su estructura, por la fuerza de los vínculos cognaticios. Desde los últimos siglos republicanos hasta los años finales de la época clásica, por obra de los pretores y de la jurisprudencia se forja una nueva concepción jurídica e ideológica de la institución, y se abre paso, de este modo, a su progresiva transformación: patria potestas in nostri liberi sunt, o liberi in potestate parentum esse $e^{41}$. Esta afirmación de Gayo reporta que los juristas clásicos superación la tesis de una patria potestas concebida como poder material ligado al ejercicio del mancipium corporal primitivo, y una tendencia a su diseño como un derecho abstracto civil (ius). Potestas que, además, deberá ser ejercida de una forma más humanitaria y equitativa por el paterfamilias. En este sentido, se debe poner en valor la tesis acertada de Antonio Fernández de Buján quien manifiesta que la patria potestad "en la práctica, su ejercicio se venía limitando por las costumbres de los antepasados, mores maiorum, contrarias a todo abuso en la conducta paterna, y por la ritual consulta al tribunal denominado iudicium domesticum", así como por "otros elementos disuasorios del ejercicio de la patria potestad" como fueron la nota censoria y la legislación imperial ${ }^{42}$.

Este cambio de mentalidad respondió a una concepción diferente del valor de los vínculos de parentesco y al triunfo de la familia cognaticia. Nuevos acontecimientos jurídicos que son ya muy perceptibles en los escritos de Cicerón $n^{43}$,

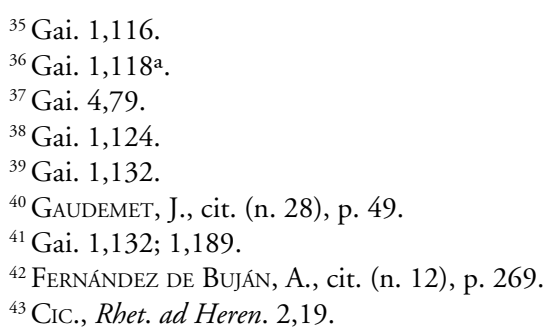


quien mantiene que los vínculos cognaticios se deben fundar en la naturaleza y en el amor filial (pietatis causa) que deben guardar los padres a los hijos. Del mismo modo, esta evolución emerge en la obra literaria de Valerio Máximo ${ }^{44}$ y en el edicto del pretor. Desde la óptica de la economía, en este nuevo escenario histórico y jurídico, Roma se convierte en un vasto imperio comercial y en una potencia mundial. La familia agraria tradicional es abandonada por los romanos en beneficio de una nueva familia urbana y de los negocios. En esta dirección, como informa Ulpiano, la creación de un edicto para los negocios realizados por los que estaban bajo patria potestad (que originó tres acciones y procesos para el comercio, la empresa y la industria: de peculio, in rem verso, quod iussu ${ }^{45}$ ) responde a aquella transformación.

En consecuencia, si la patria potestad arcaica fue un poder que se ejerció sobre los hijos, en interés de la unión personal y patrimonial de la familia (en esta circunstancia es donde se concentra su fuerza y razón de ser), sin embargo, en los tiempos republicanos tardíos e imperiales, la institución se perfiló como un poder jurídico que se debía ejercer conforme a unos deberes (officium) de protección y cuidado de los liberi. La vigencia de esta nueva concepción de la patria potestad se reporta por Gayo $(2,157)$ quien sostiene que los sometidos sub potestate son herederos domésticos (heredes domestici) y son considerados como si fuesen dueños del patrimonio de la familia en vida del padre: "quoque parente quodammodo domini existimantur". Es obvio que la patria potestad ha evolucionado y se ha dulcificado. Esta afirmación habría sido inconcebible para la jurisprudencia pontifical. En la fase arcaica de Roma, la patria potestad era un derecho absoluto del paterfamilias y no generaba relaciones jurídicas de derechos y obligaciones bilaterales entre padre e hijos.

Si se acepta este tránsito histórico - jurídico de la patria potestad, se debe admitir que esta nueva concepción debió influir tanto en el modo como en la intensidad de la aplicación de la potestas sobre los sometidos, es decir, en la forma de ejercer las facultades jurídicas que brotan del ejercicio de este poder. Sin embargo, se debe advertir que las nuevas circunstancias e influencias jurídicas, económicas y éticas no van a suprimir ni alterar rápidamente el número de facultades, ni la naturaleza jurídica de la patria potestad como un poder absoluto, jurídico y político, supremo de gobierno del paterfamilias ${ }^{46}$ sobre sus descendientes. El cambio de mentalidad y el cambio del gobierno en su ejercicio se produjeron de modo gradual y progresivo.

Las facultades jurídicas que brotaban de la patria potestad romana arcaica, ius vitae et necis (Tab IV,2), expositio, mancipatio in causa mancipii, ius vendendi, no pasaron desapercibidas a los historiadores antiguos y clásicos. Dionisio de Halicarnaso $(2,22)$ calificó aquel poder de tiránico. No es de extrañar este apelativo, si tenemos en cuenta su naturaleza. Desde los primeros tiempos, a tenor de la información que nos han transmitido las fuentes literarias y jurídicas de la época arcaica y clásica, las facultades más intensas que brotan de la patria potestad, de

\footnotetext{
${ }^{44}$ VAL. MAX. VII,7,2.

${ }^{45}$ D. $15,1,1,2 ; 15,1,1,3$.

${ }^{46}$ De la Torre, J. M., cit. (n. 34), p. 76.
} 
las que goza el pater familias, son el ius tollendi o derecho de reconocer la filiación del recién nacido como miembro del clan familiar ${ }^{47}$, el ius exponendi, o derecho de abandono de los hijos recién nacidos ${ }^{48}$, el ius vendendi, o derecho de venta como esclavo fuera de las fronteras de Roma, el ius noxae dedidito, o entrega de los hijos en régimen de semiesclavitud penal y el ius vitae et necis, o derecho de vida y muerte sobre los hijos. Este poder del paterfamilias sobre la uxor in manu, es similar a la patria potestas. El marido puede disponer de la mujer. En este sentido, si creemos a Tertuliano (Apolog., 39,10), Catón prestó su esposa a sus mejores amigos para que les diese hijos. Del mismo odo, el paterfamilias debe prestar su autorización al hijo y a la filia familias sub potestate para contraer matrimonio cum manu válido: "eorum, qui in potestate patris sunt, sine voluntate eius matrimonia iure non contrahuntur" (PS. 2,19,2). Poderes inhumanos, atroces, sin duda, que hacían estremecer a las generaciones posteriores como se deduce de los escritos de Dionisio de Halicarnaso, pero poderes de los que los ciudadanos romanos se sentían orgullosos frente a otros pueblos y naciones, como es perceptible en los escritos de Gayo. En virtud de estos poderes, el paterfamilias puede disponer libremente de sus hijos por razones de fuerza mayor, pobreza, hambre, el paterfamilias puede abandonar a los recién nacidos, ius exponendi, (según Dionisio de Halicarnaso, previa denuncia a cinco vecinos ${ }^{49}$ ).

El pater familias puede vender ${ }^{50}$, según Dionisio de Halicarnaso, a partir de los tres años de vida ${ }^{51}$ a los alieni iuris. Si es cierta la noticia, probablemente, este plazo de tres años se explicaría porque es el tiempo de vida que los recién nacidos tenían asegurado para ser lactantes. De este modo, si el hijo era reconocido por el pater familias, ius tollendi, éste debía esperar al menos tres años para venderlo como esclavo, decisión que aquel podía tomar por motivos económicos, es decir, para evitar el hambre en su familia. Por otra parte, ningún requisito jurídico, según el historiador de las "Miniaturas Antiguas de Roma", sería necesario para que el paterfamilias pudiese dar muerte al hijo que naciese con malformaciones congénitas o deformaciones ${ }^{52}$.

Dionisio de Halicarnaso nos reporta también que el pater familias tuvo derecho de vida y muerte (ius vitae et necis) sobre los hijos ${ }^{53}$. En relación a este derecho jurídico arcaico, el paterfamilias se presentaría, bajo el poder que le es conferido por la patria potestas, como una especie de iudex que estaba facultado

\footnotetext{
${ }^{47}$ Rodríguez EnNes Luis, Bases jurídico-culturales de la institución adoptiva (Santiago de Compostela, 1978), p. 35; PerozzI, Silvio, "Tollere liberum”, en Studi Simoncelli (Napoli, 1917), p. 213.

${ }^{48}$ Cic., De legi. 3,19.

${ }^{49}$ Dion. Halic. II, 15,2.

${ }^{50}$ Dion. Halic. II, 27,1-3.

${ }^{51}$ Dion. Halic. II, 15,2.

${ }^{52}$ Cic., De leg. III,19: “Quintus: At mehercule ego frater quaero, de ista potestate quid sentias. Nam mihi quidem pestifera videtur, quippe quae in seditione et ad seditionem nata sit. Cuius primum ortum si recordari volumus, inter arma civium et occupatis et obsessis urbis locis procreatum videmus. Deinde quom esset cito necatus tamquam ex XII tabulis insignis ad deformitatem puer, brevi tempore necio".

${ }^{53}$ Dionisio Halic., Antig. L II, cap. $27^{\circ}$.
} 
para enjuiciar la vida privada y pública de sus hijos, en situaciones que pudiesen atentar contra la integridad, o reputación del grupo familiar, o por actuaciones realizadas frente a otros clanes familiares, gentilicios, o, en último término, contra la Ciudad estado. El derecho de enjuiciar a los hijos en un consejo doméstico y condenarlos a la pena capital podía evitar la cólera de otros grupos familiares, tal vez, víctimas de crímenes o actos injuriosos gravísimos cometidos por aquéllos. Hechos presuntamente criminales que podían conducir a la venganza privada y al talión. La persistencia del derecho durante siglos demuestra que la intervención del consejo doméstico se realizaba en interés de la familia, no tenía por objeto la protección del hijo. En consecuencia, la actuación jurisdiccional privada del paterfamilias refuerza, no limita, su patria potestad.

Desde una óptica procesal, los vestigios arcaicos de la patria potestad permanecen en los tiempos republicanos, pues el paterfamilias puede vindicar a los hijos mediante una legis actio sacramento in rem. Una vindicatio in rem judicial de los hijos sub potestate patris es posible todavía en los siglos II d. C. y III d. C., pues, si creemos a Ulpiano, quien sigue el parecer anterior de Pomponio, el ciudadano puede vindicar la patria potestas ex iure Quiritium de los liberi erga omnes: "si quis ita petit filium suum, vel in potestate ex iure Romano, videtur mihi et Pomponius consentire, recte eum egisse; ait enim, adiecta causa ex lege Quiritium vindicare posse" ${ }^{54}$. En este sentido, no le falta razón a Luis Rodríguez Ennes, quien manifiesta que el poder de la patria potestas "es formalmente idéntico al dominio sobre las cosas corporales y a la dominica potestas sobre los esclavos, ya que se observa cierto sentido de sinonimia en las palabras: manus, potestas, dominium, usadas indistintamente en los tiempos primitivos para denominar la propiedad quiritaria sobre las cosas y el poder paterno, marital y dominical sobre las personas" ${ }^{55}$. De acuerdo con esta posición, ya en la época arcaica, la patria potestas es un ligamen jurídico, o nexus personal, que somete a los hijos y las hijas, que crea voluntariamente el paterfamilias y que forma parte de su poder mancipium. Estas facultades de la patria potestas romana demuestran, además, que los hijos impúberes pudieron ser concebidos como una infancia mancipi o, al menos, quasi mancipi.

Aunque Luigi Capogrossi sostiene que, a partir de la información reportada por Dionisio de Halicarnaso, desde los orígenes ya encontramos un fuerte control social a los poderes de la patria potestad ${ }^{56}$, sin embargo, estas facultades, que se pueden calificar como despóticas, que emanan del gobierno de la patria potestas siguen en vigor durante todo el periodo republicano. Y parece que solo comienza a atenuarse levemente, fruto de las nuevas concepciones filosóficas estoicas, que penetran con intensidad en Roma, durante la época clásica. Inicialmente, la influencia filosófica fue un espejismo en el mundo del derecho de familia y de la patria potestad romanos. Así la lex Julia de adulteriis considera crimen el

${ }^{54}$ D. $6,1,1,2$.

${ }^{55}$ Rodríguez EnNes, L., cit. (n. 47), p. 34. En el mismo sentido se expresan Fernández de Buján, A., cit. (n. 12), pp. 268 -269; De Martino, Francesco, s. v. "Famiglia", en Novissimo Digesto Italiano, (Torino, 1981), IV, p. 44.

${ }^{56}$ Capogrossi, Luigi, s. v. "Patria potestà", en Enciclopedia del Diritto (Milano, Giuffrè, 1982), XXXII, pp. 242- 243. 
adulterio y autoriza al paterfamilias a dar muerte, sua manu occidere, tanto a la hija casada adúltera, que ha permanecido bajo patria potestad, como al hombre adúltero con el que mantuvo relaciones, so pretexto de la protección de la dignidad de la casa del paterfamilias y su descendencia ("dignitatis domi suae vel generi sui deprehensum" $)^{57}$. Sin embargo, poco tiempo después, Séneca aboga por el no maltrato de los hijos ${ }^{58}$. Esta línea de pensamiento es seguida por Adriano, quien estableció que no se podía castigar inmoderadamente a los hijos. Evidentemente, son voces autorizadas, pero tal vez se trataron de recomendaciones filosóficas y de directivas jurídicas morales sobre el modo de ejercer el gobierno de la patria potestad. Así, según nos informa Suetonio, ya en época del emperador Claudio, los padres seguían expulsando a la infancia de sus familias ${ }^{59}$. En esta dirección, la correspondencia de Plinio ${ }^{60}$ testimonia que esta praxis permanece todavía en la época del emperador Trajano. Por su parte, Séneca no cuestiona la licitud del poder del padre de familia para juzgar a sus hijos (asistido de un consejo de parientes y amigos) ni su potestad para condenarlos a una muerte segura. El filósofo, incluso, alaba que un padre pueda punir a su hijo con la pena de un destierro (= capitis deminutio máxima). Por otra parte, tampoco la disposición mencionada del emperador Adriano parece que constituyera un verdadero límite, o freno legal, a la extensión de las facultades de la patria potestad paterna. Además, de estas fuentes históricas tampoco se puede concluir una derogación expresa del ius vitae et necis.

Pero, por otra parte, es evidente que esta nueva mentalidad debió influir

${ }^{57}$ PS. 2,26,1.

${ }^{58}$ SEn., De clem. I,15: "Habiendo T. Ario sorprendido á su hijo en flagrante delito de parricidio, le formó proceso y le condenó á destierro, admirando que se contentase con el destierro, y destierro muy dulce, porque le relegó á Marsella, concediéndole igual pensión anual que antes de su crimen. Por medio de esta generosidad consiguió que en una ciudad en la que hasta los mayores malvados encuentran siempre defensores, nadie dudara que el condenado fuese realmente culpable cuando le condenaba un padre que no podía odiar. Por este mismo ejemplo podrás comparar al buen príncipe con el buen padre. Cuando juzgó á su hijo, T. Ario invitó á su consejo á César Augusto, quien acudió á los penates privados y tomó asiento en el consejo de familia extraña. No dijo: "Que venga á mi palacio.» De hacerlo así, el juez hubiese sido César y no el padre. Oída la causa y discutidas todas las pruebas, tanto las que presentó el joven como las que se alegaban en contra suya, pidió Augusto que cada cual diese por escrito su opinión, por temor de que la de César fuese la de todos. En seguida, antes de que se desplegasen los escritos, declaró que no aceptaría la herencia de T. Ario, que era muy rico. Dirá alguno que había debilidad de carácter en el temor de que se creyese que por medio de la condenación de un hijo quería abrir paso á sus esperanzas. Yo pienso lo contrario. Cualquiera de nosotros hubiese podido tener, contra las interpretaciones malignas, bastante confianza en el testimonio de buena conciencia; pero los príncipes deben conceder mucho á la fama. Juró, pues, que no aceptaría la herencia. Verdad es que Ario perdió en el mismo día otro heredero; pero César conquistó la libertad de su voto, y después de haber demostrado que su severidad era desinteresada, cosa que un príncipe debe tener presente siempre, dijo: "Que sea desterrado al punto que designe su padre.» No votó el saco, ni las serpientes, ni la prisión, atendiendo no al juzgado, sino al juicio á que asistía. Creyó que un padre debía contentarse con el castigo menos severo para un hijo, joven aún, que había sido excitado al crimen y que lo había intentado con timidez parecida á la inocencia: pareciole que bastaba alejarle de la ciudad y de la presencia de su padre".

${ }^{59}$ Suet., v. Claud., 29.

${ }^{60}$ Plin., Epist. X,66,72. 
progresivamente en el ámbito interno de la vida de las familias y en el modo de ejercer la patria potestad. En este sentido, Papiniano nos reporta que Trajano impuso a un padre de familia, por autor de malos tratos y no cumplir sus deberes de piedad, la obligación de emancipar a un hijo: "quem pater male contra pietatem afficiebat, coegit emancipare" ${ }^{1}$. El emperador ordenó, además, que el hijo expósito, que es reducido a la esclavitud por un tercero, no pierda su condición de libre ${ }^{62}$. Vemos como la humanitas y la pietas son valores filosóficos, éticos y morales que van penetrando en el campo del derecho de familia y que, en los primeros siglos después de Cristo, empapan al gobierno de la patria potestas y se van convirtiendo en sus principios rectores. Aunque, ciertamente, las intervenciones de los príncipes no derogaron de raíz las temibles facultades que emanaban de aquélla (de hecho, el emperador Trajano resolvió casos aislados de ejercicio abusivo de la patria potestad), esta tendencia limitadora del ejercicio abusivo de la patria potestad comenzó a dar sus frutos. Por ejemplo, Adriano castigó a un padre con la deportación a una isla por dar muerte a un hijo en una cacería, so pretexto de adulterio con su madrastra. La justificación de fondo de esta resolución, según manifiesta el jurista Marciano, fue que la "patria potestas in pietate debet, non atrocitate consistere" (D. 48,9,5). De este modo, la disposición de Adriano ordena de forma expresa el modo ético - jurídico que se debe seguir para llevar a cabo el gobierno ("debet") de la patria potestad. Ahora, desde la óptica del derecho clásico imperial, la patria potestad clásica se perfila como un gobierno de piedad (= vivienda, alimentación, vestido, educación, instrucción) que se debe ejercer en interés de los sometidos.

Posteriormente, en los primeros decenios del siglo III d. C., el derecho de vida y muerte de los sometidos todavía sigue en vigor, aunque sufre serias limitaciones. Si creemos a Ulpiano, el padre de familia no puede matar a su hijo sin que haya éste haya sido oído. Por ello, el paterfamilias es obligado a acusarle ante el tribunal del prefecto o del presidente de la provincia ${ }^{63}$. El fragmento, que es reportado por el jurista clásico (D. 48,8,2), establece varios frenos y controles procesales a la posibilidad del ejercicio del ius vitae et necis. El precepto exige acusación y vista pública ante el praeses provinciae o el praefectus. En consecuencia, este derecho solía podía ser declarado y ejecutado en virtud de una sentencia judicial firme.

Este cambio de tendencia en el ejercicio de gobierno de la patria potestad (más benigna y en interés de los hijos) se extendió a otros campos del derecho de familia. En este sentido, Paulo nos informa que si una hija contrae matrimonio sin consentimiento del padre, el contrato no se resuelve ("contracta non solvuntur"64). Posteriormente, en esta misma dirección, Diocleciano y Maximiano (285 d. C.) ordenaron que el padre de familia pague los gastos de nutrición y crianza de la hija expósita, si quiere oponerse a su matrimonio: "Patrem, qui filia exposuit, hanc nunc adultam sumtibus et labore tuo factam matrimonio coniungi filio desiderantis

\footnotetext{
${ }^{61}$ D. $37,12,5$.

${ }^{62}$ Plin., Epist. X,66,72.

${ }^{63}$ D. $48,8,2$.

${ }^{64}$ OS. $2,19,2$.
} 
favere voto convenit. Qui si renitatur, alimentorum solutioni in hoc solummodo casu parere debet" ${ }^{65}$.

Posteriormente, en el Bajo Imperio, por una influencia notable del Cristianismo sobre las instituciones de la familia, Constantino limita y deroga algunos de los poderes que emanaban de la institución:

a) El ius vitae et necis deja de ser una facultad ligada a la patria potestad. Este derecho comienza a ser considerado ahora como crimen público de parricidio: "si quis parentis aut filii aut omnino affectionis eius, quae nuncupatione parricidii continenetur, falta properaverit, sive clam sive palam id fuerit enisus, poena parricidii punietur" ${ }^{66}$. La pena impuesta por el emperador al parricida es la poena cullei. Para ejecutarla, el parricida es metido en un saco de cuero con un perro, un gallo, una víbora y una mona, y echado a un mar o río, según las circunstancias de cada región. La justificación jurídica de tal pena atroz fue que el parricida debe perder el uso de todos los elementos, "sobreviviendo se le prive del cielo y muerto de la tierra" (319 d. C. $)^{67}$. Por su parte, y en esta misma dirección, Valentiniano, Teodosio y Arcadio (335 d. C.) niegan la posibilidad del indulto a los parricidas y dejan entrever la influencia cristiana en sus constituciones. Los emperadores califican el delito de parricidio como crimen atroz y sacrílego: "sacrilego diebus sanctis indulgeat? Patiatur tormenta parricida" ${ }^{6}$.

b) Por otro lado, el derecho de abandono de los hijos (expositio) no se deroga, pero se intenta limitar en dos direcciones:

Los padres pueden abandonar al hijo recién nacido, "qui liberos scientes propia voluntate domo recens natos abiecerint", echarlo y tirarlo de casa (hijos expósitos). Sin embargo, en este caso, el emperador puede ordenar que el hijo "eumdem retineat sub eodem statu” en favor de aquel padre que recoja, eduque y críe ${ }^{69}$.

De la misma manera, si el paterfamilias natural intenta una reclamación (vindicatoria en el Bajo Imperio ${ }^{70}$ ) para recuperar al hijo abandonado, la acción no puede prosperar ${ }^{71}$.

En el Bajo Imperio romano cristiano, el derecho de abandono de los hijos nacidos no se suprimió (probablemente, por razones económicas y de subsistencia de la familia), pero se tendió a limitar normativamente, bien con la creación de un derecho de acogida y guarda permanente en favor de los terceros que los cuiden y críen, bien con la concesión del derecho de la patria potestad (mediante adopción según nos reporta un intérprete anónimo en Interpretatio a la LRW. 5,7,1) y siempre que se atestigüe ante los obispos: "si modo testes episcopales subscriptio fuerit subsecuta", (CTh. 5,7,2, Hon. et Theod.).

c) En relación al ius vendendi, Dionisio de Halicarnaso (2,27,1-3) nos había reportado que una vetusta ley regia autorizó al paterfamilias a la mancipatio de los

\footnotetext{
${ }^{65}$ CI. $5,4,16$.

${ }^{66}$ CI. $9,18,1$.

${ }^{67}$ CI. $9,18,1$.

${ }^{68}$ CI. $1,4,8$.

${ }^{69}$ CTh. 5,7,1.

${ }^{70}$ Interp. LRW. CTh. 5,6,1.

${ }^{71}$ Ibíd. 5,7,1.
} 
hijos e hijas ("infancia mancipi sub potestate patris") como esclavos. Esta facultad de la patria potestad del ius vetus tuvo un largo recorrido histórico y jurídico, aunque algunos autores, como Luigi Capogrossi, han creído ver en la emancipación de la Ley de las XII Tablas una limitación al ejercicio de este derecho ${ }^{72}$. Sin embargo, debemos recordar que esta institución nació con el fin de permitir a los padres el poder renunciar al derecho y ejercicio de la patria potestad. La emancipación fue un derecho en beneficio del paterfamilias, no fue concebido en interés de los hijos. Fruto de ella, los sometidos sufren capitis deminutio, cambio de status y se hacen extraños al grupo familiar. Además, el padre de familia puede emancipar a los hijos en cualquier edad. No existían frenos legales al ejercicio de este derecho, porque no nació como medida limitadora de la patria potestad. No parece haber existido en Roma un derecho de emancipación -derecho de mayoría por edad legal- en beneficio de los hijos. Éstos nunca pudieron exigir a su padre su liberación jurídica. Pero, sí es cierto, que los emancipados fueron protegidos durante la República y en la época clásica, por razones económicas y militares.

Ya en los inicios del Bajo Imperio, las primeras limitaciones del derecho de venta de los hijos parecen provenir de Diocleciano y Maximiano, quienes en una constitución imperial confirman, que es manifiesto para el derecho civil, que los hijos e hijas (sub potestate patris) no pueden ser transferidos a terceros por causa de venta, donación, prenda, ni por cualquier otro modo jurídico, aunque el adquirente desconociese la condición jurídica de los hijos e hijas alienados (293 d. C. -305 d. C. $)^{73}$.

Poco tiempo después, el emperador Constantino justifica el ejercicio de este derecho de venta de los hijos en situaciones de extrema pobreza, o hambruna. El emperador sostiene que sólo en estos supuestos está justificada la venta de lo hijos y de las hijas recién nacidos (es un medio de supervivencia del pater y de su familia). Por otra parte, el emperador impone al comprador la obligación de destinar al niño adquirido a servir o trabajar para este, y crea un derecho de rescate en favor del padre legítimo, quien puede pagar un nuevo precio en metálico (se comprenden gastos de crianza, educación, instrucción y formación etc.) o bien ofrecer a cambio un esclavo. En ambos casos, el hijo o la hija pueden volver de nuevo la condición de ingenuos libres (sub potestate patris $^{74}$ ).

En realidad, la constitución imperial confirma una práctica familiar socialmente admitida e inveterada en el tiempo, que se debía realizar tanto con los recién nacidos como con los hijos e hijas que estuviesen en edad de trabajar, pues representaba un medio eficaz de liberación de las cargas y de la ruina económica de la familia. Sin embargo, esta praxis condujo a frecuentes abusos de los padres de familia, quienes, guiados por la avaricia del dinero, vieron en este derecho un modo de conseguir fines lucrativos perversos. En este sentido, y en relación a los hijos (sub potestate patris) entregados en noxia, o servidumbre, en favor de terceros, las constituciones de Constantino intentaron reprimir el abuso, la tiranía, la avaricia, y la explotación atroz del trabajo infantil de los hijos tanto

\footnotetext{
${ }^{72}$ Capogrossi, L., cit. (n. 56), p. 245.

${ }^{73}$ CI. $4,43,1$.

${ }^{74}$ CI. $4,43,2$.
} 
frente a quienes los daban, so pretexto de la comisión de una injuria, como frente a quienes los retenían en servidumbre, so pretexto de ser reos de la misma injuria ("qui scientes ingenuos servitutis necessitatem per iniuriam sustinere dissimulant") con el fin de beneficiarse y procurarse ganancias desmedidas ("universo devotionis studio contendant, si quis ingenuis natalibus procreatos sub tyranno ingenuitatem amississe aut propia contenti conscientia aut aliorum indiciis recognoscunt, natalibus suis restituere, nec exspectata iudicis interpellatione. Nam si quis contra conscientiam suam vel certissima testimonia plurimum in eadem avaritiae tenacitate permanserit, severisima poena mulctabitur" ${ }^{\prime \prime}$ ).

d) En relación al consentimiento paterno para contraer matrimonio por las hijas que se encuentran bajo patria potestad, Honorio y Teodosio ordenaron que se debe atender a la voluntad del padre, considerado como una facultad de auxilio que surge de la patria potestad. Si la hija es sui iuris, pero menor de veinticinco años, se debe investigar el asentimiento. Si estuviera privada del padre se requiere el parecer de la madre, de sus parientes y de ella misma: "in coniunctione filiarum in sacris positarum patris exspectetur arbitrium. Si sui iuris puella sit intra quintum et vicesimum annum constituta, ipsius quoque assensus exploretur; si patris auxilio destituta, matris et propinquorum et ipsius quoque requiratur adultae iudicium"77.

\section{Orientación de la patrística de la etapa clásica y del Bajo Imperio}

Los principios filosóficos cristianos del Bajo Imperio (pietas, caritas, y miseri$\operatorname{cordia}^{78}$ ) sustituyen a los valores filosóficos y éticos clásicos encarnados en el officio, la pietas y la humanitas $^{79}$. Aquéllos son ahora los valores palpables que ofrece la nueva religión. Principios rectores que deben regir a la nueva infancia romana y cristiana. La razón de este giro jurídico reside en la involución que comienzan a sufrir las estructuras jurídicas y religiosas del Imperio. En este tiempo, como acertadamente manifiesta Jesús Daza Martínez (a propósito de un estudio de las querellae de inoficiosidad) "subyacen concepciones innovadoras relativas tanto a la patria potestad como al parentesco civil agnaticio, ya que suponen el progresivo reconocimiento jurídico de los vínculos naturales de consanguinidad" 80 , "el reconocimiento de la equiparación de los hijos en el plano familiar y hereditario, y el tratamiento conjunto de la sucesión testamentaria materna y la del paterfamilias" ${ }^{81}$. La Iglesia penetra en las entrañas públicas del Imperio y la ideología cristiana va a ir empapando las instituciones civiles del derecho romano, allí donde exista un punto de encuentro. Por ello, el matrimonio, el divorcio, la familia, la patria

${ }^{75}$ CTh. 5,6,1.

${ }^{76}$ CTh. $5,6,1$.

${ }^{77}$ CI. 5,4,20.

${ }^{78}$ CI. $5,7,1$.

${ }^{79}$ Sen., De clem. I, 1-15.

${ }^{80}$ Daza MarTínez Jesús, "Portio debita" y comunidad familiar en cuanto claves interpretativas de una sintesis histórico-comparada en materias de liberalidades mortis causa, en IV Congreso Iberoamericano de derecho Romano, Ourense, 17-18 de abril de 1998 (Vigo, Ediciones de la Universidad de Vigo, 1998), I, p. 93.

${ }^{81}$ Ibíd. 
potestad y su ejercicio son instituciones que serán abordadas exhaustivamente por los primeros Padres de la Iglesia, quienes combatirán cualquier ropaje de forma y contenido paganos ${ }^{82}$. La jerarquía vigilará tanto la redacción de nuevos preceptos como la resolución de aquellos casos jurídicos, cuyo resultado si se aplicasen por el derecho civil romano, serían pecado capital. Esta es la regla de oro que guiará progresivamente las nuevas relaciones del derecho civil romano con el cristianismo en el Bajo Imperio. Contactos que se intensifican a medida que la Iglesia adquiere más fuerza política sino de decisión sí de persuasión en las cancillerías imperiales. Influencia que se proyectará, posteriormente, a las cortes y asesorías jurídicas nobiliarias de los reyes feudales, durante toda la Alta Edad Media.

Esta influencia cristiana en el derecho romano postclásico fue muy perceptible en los poderes que originaba la patria potestad. Para el cristianismo, el derecho de vida y muerte y el abandono de los hijos recién nacidos no sólo se presentaban como derechos atroces, sino como pecados capitales bíblicos, que el derecho civil no podía regular ni proteger. Pecados que no pueden ser cobijados por el seno de la nueva familia que quiere Dios. Del mismo modo, la avaricia, el egoísmo y la codicia de los bienes son pecados que afloran al abrigo de un ejercicio desmedido de la patria potestad romana mediante la explotación de los hijos. La explotación laboral infantil de los hijos constituye otro pecado grave. La Iglesia intervendrá directamente en todos aquellos asuntos jurídicos civiles de la familia que tengan contacto o relación con las Sagradas Escrituras (Antiguo y Nuevo Testamento). Un ejercicio atroz de la patria potestad es pecado mortal. Del mismo modo, el matrimonio consensual romano, aunque en un primer momento es respetado por los primeros Padres de la Iglesia, progresivamente se conceptualiza como un vínculo indisoluble ${ }^{83}$ que se perfecciona mediante la cópula de los contrayentes y constituye un sacramento ${ }^{84}$. De este modo, y poco a poco, el derecho romano entra bajo la competencia y la mirada fiscalizadora de la Iglesia. En definitiva, como afirma convincentemente Gaudemet, “¿Iba a librarse el derecho de la influencia de las ideas nuevas, de la moral enseñada por los Padres de la Iglesia?" 85

En este nuevo marco histórico y jurídico, la Iglesia quiere convertir a la familia romana pagana en una familia cristiana. El sirio Taciano aboga, ya en el siglo II d. C, por unir en matrimonio a Dios con el hombre (Tacian., Orat. ad Graecos $13)^{86}$. Atenágoras, filósofo ateniense, cristiano, de la misma época, intercede por la unión en matrimonio del alma de los cristianos con Dios (Atenag., De res. 2,20). Las nuevas corrientes evangelizadoras empapan de una nueva carga ideológica y ética el derecho y las instituciones jurídicas del matrimonio y la familia. La pugna entre la fe y la ley romana se hacen perceptibles también en los escritos de

\footnotetext{
${ }^{82}$ Rodríguez Díez José, Indisolubilidad y divorcio en la historia del matrimonio cristiano y canónico ¿Indisolubilidad relativa al futuro? en Anuario Jurídico y Económico Escurialense, 39 (2006), pp. 174-179.

${ }^{83}$ Gaudemet, J., cit. (n. 28), pp. 73-74.

${ }^{84}$ Ibíd., p. 71.

${ }^{85}$ Ibíd., p. 64.

${ }^{86}$ De la Torre, J. M., cit. (n. 34), p. 214.
} 
San Pablo ${ }^{87}$ y San Agustín ${ }^{88}$. Con todo, a partir del siglo IV d. C., los acontecimientos históricos y jurídicos se impregnan de una ambiente teocrático ${ }^{89} \mathrm{y}$, al decir de Gaudemet: "los concilios, más numerosos en Oriente que en occidente, comenzaron a formular reglas en materia de matrimonio" ${ }^{\circ 0}$.

La nueva familia romana se funda en el matrimonio (vínculo ahora indisoluble para Jerónimo, Ambrosio y Agustín ${ }^{91}$ ) que hace nacer una comunidad de vida de dos unidos en uno ${ }^{92}$. Además, según el “Águila de Hipona”, los cónyuges fundan su unión en la consecución de los bienes del matrimonio: fides, prole, sacramentum (fidelidad, hijos, sacramento). Agustín apuesta por la cooperación activa de ambos cónyuges en los bienes de la familia, es decir, en la procreación y educación de la prole.

Sin embargo, los Padres de la Iglesia no discuten la autoridad del paterfamilias sobre su esposa. Tampoco su competencia exclusiva para ejercer la patria potestad. Así, al decir de Tertuliano (De resurrect. carnis 63,1): "el alma no será acogida desnuda por el esposo, como una ramera; al contrario, tiene a la carne como instrumento suyo, como ornamento, como sierva". También, en este sentido, Juan de Churruca manifiesta que "le christianisme a maintenu la soumission de la femme à l'homme en tout ce qui cocerne la structure de la famille et l'organisation des communautés" 93 . Cristo es hombre, es un varón. El hijo de Dios. La mujer es sometida y está al servicio ancilar del hombre paterfamilias y de los hijos (sub potestate).

De acuerdo, con estos principios rectores, es de justicia sostener que los Padres de la Iglesia del Bajo Imperio romano intentaron influir en la naturaleza de la familia, de la patria potestad y en su ejercicio. En este sentido, San Clemente de Alejandría ${ }^{94}$ asimila la familia romana a la Iglesia. En el libro II de su Paedagogus, aborda instituciones del derecho de familia, como el matrimonio, la educación, la alimentación y los vestidos. Temas relacionados directamente con el ejercicio de la patria potestad. Por su parte, San Juan Crisóstomo atribuye al padre el poder y la dirección de la educación, así como la instrucción sobre su esposa y los hijos ${ }^{95}$.

\footnotetext{
${ }^{87}$ Ibíd., p. 138.

${ }^{88}$ August. Hipon., De nuptiis et concupiscentia, 1,10; Epist. VIII (Patr. Lat. IL, 42b).

${ }^{89}$ De LA Torre, J. M., Literatura cristiana antigua, entornos y contenido, V: Desde las postrimerías del Imperio romano de occidente hasta los albores de la oscura Edad Media, (Zamora, Ediciones Monte Casino, 2009), p. 402: "todos los acontecimientos de este periodo se desarrollan en una atmósfera impregnada de cristianismo, a la que cabe calificar de 'hierocrática', o también de 'teocrática'. Y esto, tanto en oriente donde los emperadores asocian su destino al de la religión oficial, como en occidente donde el derrumbamiento de las instituciones imperiales sólo representa un perjuicio temporal para la Iglesia, que rápidamente se adapta a la nueva situación y que bien pronto se beneficia de ella. El imperium ya no existe; la Iglesia rompe su auctoritas. Los jefes bárbaros no pueden desconocer el hecho cristiano del cuál sólo se les reconoce un simple poder de administración (potestas)".

${ }^{90}$ Gaudemet, J., cit. (n. 28), p. 64.

${ }^{91}$ Rodríguez Díaz, J., cit. (n. 82), p. 179.

${ }^{92}$ Mt. 19, 6.

${ }^{93}$ Churruca, Juan de, Egalité et inegalité des conjoints dans le mariage chrétien, en EL MISMO, Cristianismo y mundo romano (Bilbao, Ediciones de la Universidad de Deusto, 1988), p 61.

${ }^{94}$ De Alejandría C., Strommata, vol. IIII,10, (Patr. Graec. VIII, col. 1, 169).

${ }^{95}$ Crisóstomo, Joh., In Gen 7,1 (Patr. Graec. LIV, col. 608).
} 
San Cirilo, por su parte, aboga por el deber que incumbe al padre de hacer nacer al hijo en la catequesis y en Cristo ${ }^{96}$. También San Agustín ${ }^{97}$ sostiene que el padre ejerce sobre la familia la misma función de cuidado y vigilancia que los obispos sobre los cristianos. Toda esta carga evangélica y pastoral no podía ser preterida por el derecho romano, e impregnó a la concepción jurídica del matrimonio, de la familia y, sin duda, al ejercicio de la patria potestad.

\section{La PATRIA POTESTAD EN EL DERECHO VISIGODO}

La patria potestad y las relaciones paternas y filiales entran en un nuevo marco jurídico tanto en el reinado de Justiniano en Oriente (527 d. C. -565 d.) como en el reino visigodo de Occidente. En esta dirección, según el decir convincente de Luis Rodríguez Ennes, "en Oriente los vínculos cognaticios van sustituyendo progresivamente a los agnaticios hasta el punto de que en la época justinianea, puede decirse que, tanto de la antigua institución de la patria potestas como de la concepción jurídica de la adopción, sólo sobrevive el nombre" ${ }^{98}$.

Por su parte, en Occidente, a mediados del siglo V d. C., desaparece la unidad política y jurídica del Imperio ${ }^{99}$, y se da paso al período de la Alta Edad Media. En relación a Hispania, ésta rompe su cordón umbilical con Roma fruto de las invasiones germánicas de los pueblos godos. De este modo, se inicia el encuentro de la población romana bajo imperial asentada en el solar hispánico con la nueva población goda y con los judíos. Este nuevo periodo histórico es, sin duda, una confluencia de etnias y religiones. Una etapa, que al decir de Juan María de la Torre fue además "convulsiva y transitoria" ${ }^{100}$. Y tal vez, por ello, el mayor desafío de los reyes godos fue la integración de las diferentes tendencias y sensibilidades. Un nuevo y pequeño mundo territorial, diverso, conquistado a Roma, para el que legislar y gobernar.

Los monarcas visigodos encontraron la solución a sus nuevos desafíos en el derecho romano vulgar del Bajo Imperio (representado principalmente por el Código Gregoriano, Código Hermogeniano, Código Teodosiano, las Novelas Posteodosianas, las Sentencias de Paulo, el libro I Responsorum de Papiniano y el Epitome Gai). Este derecho pervivió en la administración y en la organización jurídica territorial de la Hispania visigoda: "Romani, quos Visigothi subegerant, suo iure vivebant" ${ }^{101}$. Los reyes visigodos respetaron las estructuras administrativas del

${ }^{96}$ De Jerusalén, C., Catequesis XV (Patr. Graec. XXXIII, col. 895, 14)

${ }^{97}$ August. Hipon., In Joanni. S. Evangelium LI (Patr. Lat. XXXV, col. 1768).

${ }^{98}$ Rodríguez EnNes, Luis, La adopción romana: continuidad y discontinuidad de un modelo, en Revista Dereito, 18 (2009) 1, p. 119.

${ }^{99}$ Gaudemet, J., cit. (n. 28), p. 113.

${ }^{100}$ De la Torre, J. M., cit. (n. 34), p. 406. Gaudemet, J. cit. (n. 28), p. 114, manifiesta que "La entrada de los germanos en el suelo del Imperio, su establecimiento junto a la población local de tradición jurídica romana, y luego la fusión progresiva de los dos grupos, aportaron en materia matrimonial nuevas concepciones que, lejos de integrarse en el sistema romano, contribuyeron durante seis o siete siglos a bastardearlo".

${ }^{101}$ Hänel, Gustav, Compositio Legis Romanae Visighotorum (Lipsiae, 1848), cap. $1^{\circ}$.

LRW, Auctoritas Alarici Regni. 
Bajo imperio romano ${ }^{102}$, pues, fruto de sus conquistas, se encontraron con una población romana que ya estaba siendo gobernada con aquel cuerpo normativo jurídico, que era muy disperso. Tal vez, fuera este el motivo de la codificación de la Lex Romana Wisigothorum que fue llevada a cabo posteriormente por el Rey Alarico, en el año 506 d.C. ("Alaricus Tolosae promulgavit anno imperii sui XXII"103) en presencia de los "sacerdotes et nobiles viros que in lucem intelligentiae melioris deducta resplendeat"104, sancionado "episcoporum vel electorum provincialium nostrorum roboravit assensus" 105 en la ciudad gala de Adge. Esta "Ley romana de los visigodos" supuso la toma de la iniciativa legislativa y eclesiástica por Alarico II en Hispania, quien "Euricum patrem imitatus"106.

En esta nueva etapa de nuestra historia comienzan las relaciones jurídicas del derecho romano vulgar del Bajo Imperio con las costumbres de los nuevos pueblos invasores. Relaciones que fueron impregnadas por el Cristianismo, religión doctrinal que, siguiendo la tradición del Bajo Imperio romano, trató de seguir influyendo en aquellos campos del derecho público y privado que pudiesen tener relación directa o indirecta con el orden divino. En este asunto, el matrimonio y las relaciones jurídicas de familia no podían constituir una excepción. Así, al decir convincente de Alfonso García Gallo, a partir del siglo IV d. C, reconocido el Cristianismo como religión oficial, comienza su expansión en Hispania y "fue la propia Iglesia, por boca de sus obispos y sacerdotes, la que impuso a los fieles la acomodación de sus actos a los preceptos de la religión” ${ }^{107}$.

Sin embargo, las relaciones del derecho romano vulgar con la doctrina cristiana y las costumbres no fueron siempre coherentes ni pacíficas. En ocasiones, se dieron episodios convulsos, fruto de la presión que pudieron estar ejerciendo sobre los reyes visigodos los obispos y los juristas de la Iglesia, quienes en el marco de las redacciones de las nuevas leyes civiles y de las normas conciliares vinculantes, trataron de imponer en los concilios sinodales y en el consejo jurídico asesor, transformado en Aula Regia, sus tesis doctrinales en los campos más sensibles para ellos. Así, a tenor de la información histórica que nos transmiten las fuentes del Bajo Imperio, es probable, como ya mencionamos, que desde el gobierno imperial de Constantino, los obispos viniesen ya actuando decididamente en el campo de la jurisdicción civil ${ }^{108}$. Su competencia para resolver los litigios matrimoniales y de familia, mediante arbitrajes y laudos (episcopalis audientia) coadyuvó a fijar nuevas tesis y doctrinas en relación al matrimonio y a la familia ${ }^{109}$.

${ }^{102}$ De la Torre, J. M., cit. (n. 34), p. 411

${ }^{103}$ Hänel, G., Compositio, cit. (n. 102).

${ }^{104}$ LRW., Auctoritas Alarici Regni (Lipsiae, 1848), cap. $1^{\circ}$.

${ }^{105}$ Ibíd.

${ }^{106}$ Hänel, Gustav, Compositio, cit. (n. 102).

${ }^{107}$ García Gallo, A., Manual de Historia del derecho español,I: El origen y la evolución del derecho $3^{a}$ edición revisada, Madrid, 1967, p. 51.

${ }^{108}$ CI. 1,4,1 Valentinianus et Valens AA. Secundo PP.: Negotiatores, si qui ad domum nostram pertinent, ne modum mercandi videantur excedere, Christiani, quibus verus cultus est adiuvare pauperes et positos in necesitate, provideant episcopi". CI. 1,4,2.

${ }^{109}$ GAUDEMET, J., cit. (n. 28), p. 114: "La Iglesia se iba afirmando, cada vez más, en un mundo incierto. Ante la debilidad de los poderes políticos, iba cobrando autoridad. El mundo de los 
Por otra parte, un hito histórico, que propició un mayor protagonismo de la Iglesia en el matrimonio, la familia y la patria potestad, fue el abandono definitivo del Arrianismo por el rey Recaredo en el III Concilio de Toledo (589 d. C.), y su posterior conversión al cristianismo. El acontecimiento supuso el triunfo definitivo de la Iglesia católica romana, ya que pasó a ser la nueva autoridad religiosa dominante. Su doctrina se constituyó en un serio control y en un filtro que se debía conciliar con el derecho romano vulgar en el reino visigodo de Hispania. Esta coexistencia de las relaciones entre las fuentes jurídicas civiles y las tesis religiosas, y la posible influencia de la Iglesia en el derecho romano vulgar, se delatan ya por el IV Concilio de Toledo.

Estas relaciones de la Iglesia con las monarquías visigodas no debieron estar exentas de tensiones. En este sentido, al decir de José Rodríguez Díez, "en este contexto civil y jurídico no cristiano, la jerarquía de la Iglesia va elaborando y consiguiendo, no sin tensiones, normativa propia a lo largo del primer milenio con aportes de concilios, colecciones canónicas y decretos pontificios ${ }^{110}$ ". En consecuencia, el derecho visigodo se venía configurando como un derecho romano cristiano impregnado de elementos consuetudinarios germánicos de carácter vulgar. En este tiempo, la Iglesia es depositaria del derecho romano del Bajo Imperio y de las esencias jurídicas del mundo antiguo. En este sentido, son muy convincentes las reflexiones de Juan María de la Torre quien afirma que "los visigodos eran los más cultos entre los pueblos bárbaros, debido a sus continuas y estrechas relaciones con Roma. No obstante su escaso número ejercieron cierta influencia sobre las instituciones romanas. La lengua de los godos no pudo imponerse al universal latín y penetró solamente en algunas instituciones jurídicas. La cultura era de índole hispano romana y esencialmente eclesiástica, radicada en determinados centros, escuelas episcopales y algunos monasterios. Esta cultura mantuvo un estrecho contacto con la griega, debido a presencia de Bizancio en la franja levantina. Caso único en la Europa bárbara, muchos de los hombres cultos de la Hispania visigoda conocían la lengua y la literatura griegas, y algunos residieron largas temporadas en Bizancio"111. Más allá parece ir Alfonso García Gallo para quien "si en principio la población visigoda se regía a un tiempo por el derecho secular y por el ordenamiento jurídico canónico, a partir del siglo VI esta dualidad de ordenamientos desapareció en la práctica, al intervenir la Iglesia en la redacción de las leyes reales e incluso sancionar ella misma las más importantes, y al promulgar también los reyes las establecidas por los concilios"112

En este nuevo teatro histórico y jurídico del microcosmos y la cosmovisión alta medieval, la patria potestad visigoda es la patria potestad romana con formas

clérigos salvó en parte la herencia intelectual de la antigüedad clásica. En su ciudad, el obispo, además de pastor, solía ser protector, y hasta defensor contra los peligros, y juez o árbitro de as desavenencias. Reunidos en concilios, provinciales, regionales, a veces nacionales (algunos en las Galias, muchos más en Hispania), los obispos se esforzaron por fijar una doctrina matrimonial. La jurisdicción y la legislación eclesiástica se fueron reforzando y desarrollando”.

\footnotetext{
${ }^{110}$ Rodríguez Díez, J., cit. (n. 82), p. 176.

${ }^{111}$ De la Torre, J. M., cit. (n. 34), p. 412.

${ }^{112}$ García Gallo, A., cit. (n. 108), p. 55.
} 
cristianas heredada del Bajo Imperio Romano. Patria potestad que ejerce el paterfamilias, y se constituye en el elemento aglutinador de la prole de la nueva familia romano-germánica cristiana. Familia que permanece unida mediante nexos y sentimientos de consanguinidad. Por ello, es obvio, que la institución se sometió a la presión y a la vigilancia de la nueva jerarquía eclesiástica visigoda. En este sentido son reveladoras las afirmaciones de nuestro San Isidoro de Sevilla, quien afirma que "ius naturale est commune omnium nationum, et quod ubique instinctu naturae, non constituione aliqua habetur; ut viri et feminae coniunctio, liberorum sucessio et educatio". El matrimonio, la sucesión hereditaria y la educación de los hijos, que es una de las funciones de la patria potestad, son instituciones jurídicas del derecho natural, que forman parte del instinto natural de todos los hombres, gentes y naciones. Para nosotros, la novedad de este pasaje es que San Isidoro sitúa el matrimonio y la patria potestad (educación de la prole) en la tradición del ius naturale y del ius gentium de la civilización romana. La afirmación es muy novedosa, pues se desmarca de la tesis, al menos de la idea o corriente, sostenida por parte de la Patrística Cristiana del matrimonio cristiano como generador de un vínculo sagrado. De las afirmaciones de San Isidoro se deduce que éste aboga en favor del matrimonio y de la familia, cristianos, pero también en favor de los vínculos de consanguinidad como nervios de cohesión de la nueva familia. Todas estas instituciones jurídicas (matrimonio, familia, patria potestad) deben regirse por el ius naturale. Este derecho, al decir de San Agustín, estaba llamado a constituirse, sin duda, en uno de los principios rectores, junto al Cristianismo, de la nueva familia y del nuevo modo de gobierno que debería seguir el ejercicio de la patria potestad.

En los inicios del siglo VI d. C., la Lex Romana Visigothorum de Alarico había abrazado tanto al derecho jurisprudencial vulgarizado (mediante la adopción del Epitome Gai y de las Sententiae Receptae Pauli) como a las leges oficiales de la legislación teodosiana y posteodosiana. Las compilaciones mixtas de iura et leges fueron compendios de normas del derecho romano postclásico oficial vulgar, que ya revestían en sí mismos ropajes cristianos. Iura et leges que fueron reguladoras de la patria potestad. Institución romana transformada por el derecho clásico y del Bajo Imperio, que fue adoptada posteriormente por la legislación visigoda ${ }^{113}$ , y que la Iglesia de Alarico quiere seguir conciliando con las Sagradas Escrituras. En esta dirección, el ius vitae et necis (que ya fue regulado por Constantino como crimen de parricidio (CTh 6, 5, 18) sigue siendo considerado como tal por Alarico (LRW. 6, ,18). El ius exponendi se intenta limitar ahora por el rey visigodo (LRW $5,7,1)$. Este freno al ejercicio de la patria potestad fue comentado por el jurista anónimo intérprete de la $L R W$.: Interpretatio 5, 71: "Quicumque expositum recenti partus, sciente patri vel matre vel domino, collegerit ac suo labore educaverit, in illius, a quo collectus est, potestate consistat, seu ingenuum seu servum, quem nutrivit, esse voluerit, et si adoptare voluerit in filum vel liberum aut in servitium permanere, propia utatur potestate".

${ }^{113}$ MerêA Paulo, O poder paternal na legislação visigótica, en Estúdios de direito visigótico (Coimbra, 1948), p. 22. 
Si un niño recién nacido es abandonado y posteriormente es recogido bien por otro padre, o bien por otra madre, ope legis se transfiere un poder y derecho de custodia en su favor. Precisa, además, el jurista anónimo (quien sigue en este punto a la normativa romana bajo imperial teodosiana) que la persona que lo críe, nutre y eduque, si quiere puede adoptarlo ("si adoptare voluerit") y, de este modo, adquirir la patria potestad ope legis sobre aquél ("propia utatur potestate").

Por otra parte, una restitutio natalium ope legis trató de ser un arma jurídica cristiana eficaz para combatir la venta in noxia de los hijos que era simulada por las partes. Es decir, aquella venta simulada de los hijos con el fin de explotarlos laboralmente por el paterfamilias y el comprador. Este contrato, que ya había sido rechazado frontalmente por Constantino, fue reprimido posteriormente por el rey Alarico (LRW 5,6). Esta norma fue comentada también por el jurista anónimo del Breviario (LRW., Interp. 5,6,1): "Ingenui, qui tyranni temporibus addicti sunt servituti reddantur. Quod si quis sciens hoc ordine addictum ingenuum in servitute tenuerit, noverit in se legibus vindicandum".

Constantino ya había ordenado anteriormente la restitutio natalium en favor del hijo, lo que significaba la restitución de la ciudadanía y la libertad, e impuso penas severísimas a los que, con avaricia, persistían en mantener este negocio simulado de explotación de sus propios hijos. El hijo libre puede vindicar judicialmente su status civitatis y su libertad. Por su parte, el comentador anónimo de la LRW. cree que el fin de la normativa romano - visigoda es poner fin a la noxia tiránica en servidumbre que sufre el hijo. Y, por ende, éste puede vindicar su libertad.

Posteriormente, por su parte, el rey Chindasvinto condenó el parricidio LV. 6,5,17, "De parricidios et eorum rebus", en línea con la prohibición establecida por lex antiqua, LV. 6,5,18, "De his qui proximis sanguinis sui occiderint". Práctica legal que será seguida también, a mediados del siglo VII d. C., por su hijo Rescenvinto. Los reyes visigodos de Hispania siguieron así la tradición jurídica instaurada por Constantino. En concreto, la lex antiqua LV. 6.5,18 dispone que: "Si patrem filius, aut pater filium, seu maritus uxorem, aut uxor maritum, aut mater filiam, aut filiam matrem, aut frater fratem, aut soror sororem aut gener socerum, aut socer generum [...] vel quemcumque consiguinitate sibi proximum, aut suo generi copulatum occiderit, morte damnetur".

La lex antiqua ordenaba la condena a muerte de todos los autores de parricidio, que fuesen miembros consanguíneos de la familia. En la línea de parentesco, se comprendían los dos troncos: paterno y materno, tanto ascendientes como descendientes. La norma tiene en cuenta también las relaciones próximas de afinidad. La lex antiqua, a propósito del parricidio, nos describe quienes eran los miembros de la familia romana visigoda alto medieval: padre, madre, hijos e hijas que descienden de un matrimonio cristiano, maritus uxorem, aut uxor maritum, y sus afines.

Por su parte, Chindasvinto (LV. 6,5,16) advierte, además, que si el parricida se refugia en una iglesia o en un altar sagrado (la costumbre tiene sus antecedentes en una costumbre de la que ya tenemos noticias en la época clásica, que era realizada por los esclavos romanos, quienes se protegían en los templos romanos, al amparo de los sacerdotes, de los malos tratos y de los abusos que les inflingían 
sus dueños $\left.{ }^{114}\right)$ sea entregado por los sacerdotes cristianos a la potestad de su padre, o de los parientes más cercanos ("in potestate parentum vel propinquorum occisi tradendus est"), para que tengan poder sobre él, y para hacer de él y de sus bienes, salvada la cuota pro anima, lo que quieran. La ley adolece, sin embargo, de garantías jurídicas para el presunto acusado de parricidio, quien sin juicio previo, puede, mediante el ejercicio del talión, o de la venganza privada, ser reo de pena capital. En definitiva, estas normas protegían a la familia natural consanguínea y a sus miembros afines más próximos de los homicidios que pudieran ser cometidos por sus miembros en su seno interno. Normas que se dirigieron tanto a los godos como a los romanos, ambos pueblos cristianizados.

Por su parte, Rescenvinto (FJ. 6,5,18) sigue la línea normativa de su padre Chindasvinto, pues también condenó el ius vitae et necis y sancionó con la pena capital el parricidio. El monarca sigue la tradición legislativa de la lex antiqua LV. 6,5,18, y la disposición legal de su padre Chindasvinto, en LV. 6,5,17.

Rescenvinto estableció también: "si pater filium, aut mater filiam, aut filius patrem, aut quemlibet sibi propinquum gravibus coactis inuriis, aut dum repugnat, occiderit, et hoc idenoeis testibus, quibus merito fides possit adhiberi, apud iudicem poturit adprobare, quod parricidium dum propiam vitam tuetur admiserit securus abscedat, nec ullam vitae periculum, aut dispendia facultatum, vel tormenta formidet: illa vero discretione servata, quae in cunctis casibus est de homicidios constituta" (LV. 6,5,19). En versión del Fuero Juzgo: "si por ventura el que mata fuyere a la iglesia. $Y$ el rey ol senor lo quisieren librar de muerte por piedad, embienlo por siempre fuera de la tierra". Y si "matan a sus parientes por ocasión, esto es, "si el padre mata el fiio, o el fiio mata el padre, o la madre la fiia, o la fiia la madre, o el ermano el ermana, $o$ alguno de sus parientes mata por tuerto quel fazie el otro, o porque se quería amparar del el que lo mató, si lo pudiere esto provar ante el iuez por buenos testigos, que devan ser creydos, que defendiendo so cuerpo mató al pariente, sea quito de todo el omezillo, e non reciba poende pena ni tormento, nin dano de sus cosas, guardandose, cuemo se ndeve guardar, de non fazer el omezillo" (LV. 6,5,19= FJ. 6,5,19).

El monarca intenta corregir el ejercicio arbitrario de las propias razones, de carácter primitivo, que había sido impuesto por la ley de su padre (LV. 6,5,16) en favor de los familiares de la víctima de parricidio. Rescenvinto introdujo medidas de carácter procesal tendentes a garantizar un juicio justo al acusado, como la necesidad de una acusación judicial formal previa, la intervención de un juez y la necesidad de celebración y práctica de la prueba. El Rey exigió la existencia de dolo en el autor del parricidio, frente al parricidio involuntario, imprudente, por ocasión, y que fuese probado ante el juez por buenos testigos.

Las leyes de Recesvinto (654 d. C.) fueron limitadoras de la patria potestad romana arcaica y republicana, pues siguen la tradición romana y cristiana del Bajo Imperio. La legislación visigoda de Recesvinto se inspira en la naturalis pietas, puesta de relieve por nuestro Isidoro de Sevilla. Por ello, la patria potestad visigoda consiste en un officium que surge del amor en y por la sangre y en interés de los hijos. Las leyes visigodas protegen el matrimonio, a los padres y sus

${ }^{114}$ Gai. 1,53 . 
ascendientes, a los hijos y a los parientes más próximos consanguíneos en interés de la ratio naturalis ${ }^{115}$. Este punto de encuentro de la patria potestad romana con el cristianismo es fruto, además, de la fuerte vigilancia de la familia que realizaron durante los siglos postclásicos los Padres de la Iglesia y los obispos, quienes siempre abogaron por la unión del matrimonio y de la familia en el cristianismo y en los lazos de consanguinidad.

Esta orientación clave es seguida por nuestro Isidoro de Sevilla, quien, a también a propósito de la acción de parricidio, sostiene que compete no sólo frente a quien mate al padre, sino también a la madre y al hermano: "parricidii actio non solum in eum dabatur qui parentem, id est vel patrem vel matrem intermisset, sed et in eum qui fratrem occiderat, et dictum parricidium quasi parentis caedem"116.

Esta dirección jurídica, romano - cristiana - visigoda, es perceptible en otras prohibiciones ordenadas por Recesvinto relacionadas con el infanticidio, el ius exponendi y el ius vendendi:

El infanticidio es regulado por LV. 6,3,7 (= FJ. 6,3,7): "Ninguna cosa non es peor de los padres que non an piadat, é matan a sus fijos. E por que el pecado destos atales es spensulo tanto por nuestro regno, que muchos varones e muchas muieres son culpados de tal fecho, por ende defendemos que no lo fagan, y restablezemos que si alguna muier libre o sierva matar a su fiio, pues que es nado, o ante que sea nado prender yerbas por abortar, o en alguna manera lo afogare el iuez de la tierra luego que lo sopiere condempnela por muerte. E si la non quisier matar, cièguela: e si el marido ielo mandar fazer, e la sofrier, otra tal pena deve aver".

El ius exponendi es regulado por la ley $4^{\mathrm{a}}$, en el libro IV, título $4^{\circ}$ : “De los ninos echados" (= FJ. 4,1). Así la ley 4,4,1 prescribe que "el omne libre ó la mujer que echa el mismo debe ser siervo o sierva". La ley castiga el abandono de los niños realizado por su padre y por su madre: "si algun omne toma el ninno o la ninna echada, e lo criar, e los padres le conocieren después: si los padres son omnes libres, den un siervo por el fijo o el precio. E si non lo quisieren fazer, el iuez de la tierra los debe fazer redimir el fiio que echaron; e los padres deven ser echados por siempre de la tierra. E si non ovieren de que lo puedan redemir, aquél que lo echó sea siervo por él. $Y$ este pecado o quier que sea fecho en toda la tierra, el iuez lo debe acusar é penar". La expresión "redemir el fiio" significa la liberación del niño por imperativo legal mediante el pago de un precio en compensación, bien de un esclavo bien de una cuantía equivalente. Precio que se tiene que abonar al hombre que crió al hijo abandonado. Si el padre no lo libera, sustituye al hijo que abandonó y entra por imperativo legal en la condición de siervo, o esclavo bajo el poder de quien lo alimentó y vistió. En todo caso, si los padres no liberan al hijo expósito, el juez del lugar puede desterrar a los padres ("e los padres deven ser echados de la tierra") por el pecado cometido ("y este pecado o quier que sea fecho en toda la tierra, el iuez lo debe acusar épenar"). El ius exponendi no es un poder de la patria potestad. Para el monarca visigodo de nuestra Hispania es un pecado que justifica su prohibición, persecución y condena penal.

\footnotetext{
${ }^{115}$ Otero Varela, Alfonso, La patria potestad en el derecho histórico español, en Estudios histórico-jurídicos (Madrid, 2005), II: Derecho privado, pp. 131-132.

${ }^{116}$ SeVILla, I. de, Etymologiae V,16.
} 
El ius vendendi se tutela y prohíbe por LV. 5,4,12 (= FJ. 5,4,12): "Si el omne viendere ó diere otro omne libre, el iuez le debe prender man a mano, e fagal pechar C. sueldos doro, e aquel que fue vendido sea tornado en su estado. $\dot{E}$ si non oviere onde pague los C. sueldos, reciba C. azotes, é seal dado por siervo a aquel que fue vendido. E si de siervo vendiere omne libre o mujer libre, reciba CC azotes, e sea señalado en la fruente, è sea siervo daquel que fue vendido. Hy esto mandamos de las mujeres libres".

En otra dirección, el rey Recesvinto (LV. 3,1,3, FJ. 3,1,2) ordenó que la mujer, bajo patria potestad, que, habiendo rescindido sus esponsales, hubiese contraído matrimonio contra la voluntad de su padre, fuese entregada al poder del prometido: "si puella contra voluntatem patris alio nubat, quum sit alteri disponsata" "si quis puellam cum voluntate patris, aut aliorum propinquorum parentum, quibus ex lege huiusmodi potestas tribuitur, sponsatam habuerit, et ipsa puella contemnes voluntatem patris ad alium tendens patris contradicat, ut illi non detur cui a patre fuerit pacta, hoc ita eam nullo modo facere permittimus. Quod si ipsa puella contra voluntatem paternam ad alium quem ipsa cupierat forte pervenerit, et ipse eam uxorem habere voluerit, ambo in potestate eius tradantur, qui eam cum voluntate eius patris sponsatam habuerit". Las penas son graves: la nulidad del matrimonio, la reducción a esclavitud de la mujer y su marido, y su entrega, por el paterfamilias, al primer desposado.

Por otra parte, el monarca en LV. 3,1,5 dispuso: "Ne viris minoris aetatis maiores feminae disponsetur" (=FJ. 3,1,4: Que las mugieres de gran edad non casen con los omnes de pequenna edad) para intentar poner freno al ejercicio de la patria potestad de aquellos padres que, movidos por la avaricia ("praespostere tempus honeste lucrum dilabi cogunt ad impudicitiae lapsum") casan a sus hijos con mujeres de gran edad. El rey prohíbe este tipo de matrimonios, porque "los omnes an nombre barones, porque deben aver poder sobre las mugieres. Hy ellos quieren anteponer las mugieres a los barones, que es contra natura, cuando casan las mugeres de gran edad con los ninnos pequennos". La patria potestad debe ser ejercida conforme a natura. "Natura" significa seguir el orden natural, es decir, a las leyes del derecho de la naturaleza que gobiernan a los hombres, y su orden generacional, "doncas que la crianza de la generacion, que es mal ordenada sea tornada a su derecho". De este modo, se debe evitar el pecado del egoísmo a las mujeres codiciosas, "la edad grand de las mujeres é cobdiciosa, non quieren esperar a los barones que son tardineros". Para ello el rey quiere limitar el ejercicio de la autoridad paterna, "establecemos por esta ley, que siempre las mugieres de menor edad se casen con los barones de mayor edad", con el fin de ordenar: "ius naturae tunc directum in spem procreationis futurae transmittitur", el matrimonio cristiano ("quum nuptiarum foedus totius solemnitatis concordia ordinatur"). Nupcias, que, en esta época, se celebran por etapas, "e desde el dia de las esposais fasta dia de las bodas non debe esperar el uno al otro mas de dos annos". Todo ello, con el fin de perpetuar el orden natural de las futuras generaciones, "ordinario propagatio generis in ordinem".

Por otra parte, de acuerdo con este contexto, y según la información que nos transmiten las fuentes jurídicas, parecen ofrecer algunas dudas las tesis de quienes creen que los conceptos romanos de familia y de patria potestad roma- 
na desaparecen en el derecho del alto medievo ${ }^{117}$. Aceptar esta tesis supondría negar nuestra rica tradición del derecho romano del Bajo Imperio romano que fue heredada por el derecho visigodo de Hispania. Además, ello nos conduciría a minusvalorar la influencia de la doctrina religiosa cristiana, escolástica y civil, de los primeros Padres de la Iglesia. Los concilios y los sínodos del Bajo Imperio influyeron directamente en la institución del matrimonio y en la familia. Es por ello, por lo que se podría afirmar que en los claustros jurídicos alto - medievales de Hispania vivió la patria potestad romana, consanguínea, cristiana y visigoda. Así lo testimonia Recesvinto (LV. 4,2,13): "Matre mortua filii in patris potestate consistant. Quod si marito suppreste uxor forsitan moriatur filii qui sunt ex eodem coniugio procreati in patris potestate persistant".

En conclusión, la patria potestad, ya desde el Bajo Imperio, se vino transformando en una patria potestad romana y cristiana. Proceso evolutivo lógico que llegó al reino visigodo de Hispania. Potestas que se ejerció por el paterfamilias en interés de los hijos, en una familia anclada sobre el matrimonio cristiano y los vínculos cognaticios. Pilares jurídicos que son recogidos de forma fidedigna por la Lex Visigothorum: i) Matrimonio cristiano, viviendo de so en uno (FJ. 4, 2, 17) mas si uno dellos, o el marido, o la mujer antes que fuesen en uno ${ }^{118}$; ii) Matrimonio que genera la filiación legítima ("filii qui sunt ex eodem coniugio procreati ${ }^{119}$ ), incluso en matrimonios mixtos de godos y romanos (LV. 3,1,2; FJ. 3,1,1) y los vínculos cognaticios ${ }^{120}$ (FJ. 4: “Del linage natural'; FJ. 4,1: "Titol de los grados de parentesco", FJ. 4,1-7, del primer al séptimo grado). Filiación y grados de parentesco que deben estar en perpetua armonía con el ius naturale.

Esta evolución de la patria potestas es muy perceptible también tanto en la Lex Romana Visighotorum de Alarico como en el resto de la legislación de los reyes visigodos. Así, es indudable que las normas del Liber Iudiciorum, (654 d. C.) refrendan la vigencia de esta nueva patria potestad romano visigoda cristiana, con tintes y antecedentes jurídicos bajo imperiales. Por todo ello, nos parece muy convincente el parecer de Alfonso García Gallo quien pone luz al papel decisivo que jugó la Iglesia cristiana en la evolución de las instituciones romanas del derecho de familia en los periodos del Bajo Imperio y Visigodo en Hispania. Al decir de este magnífico historiador "fue la Iglesia, por boca de sus obispos y sacerdotes, la que impuso a los fieles la acomodación de sus actos a los preceptos de la religión: la obediencia a las autoridades, el trato humano de los esclavos, la indisolubilidad de los matrimonios, la prohibición de abandonar a los hijos, el cumplimiento de los contratos, etc. Por lo demás, la Iglesia no pretendió alterar en su conjunto el régimen económico, social o político del mundo romano, ni sustituir por otro el derecho vigente; sino tan sólo modificar aquello que contradecía su propia doctrina o dificultaba la observancia de ésta" ${ }^{121}$.

\footnotetext{
${ }^{117}$ Montanos Ferrín, Emma, La familia en la alta edad media española (Pamplona, Ediciones de la Universidad de Navarra, 1980), p. 19.

${ }^{118}$ FJ. 4,2,20.

${ }^{119}$ LV. 4,2,13.

${ }^{120}$ Rodríguez EnNes, L., Bases, cit. (n. 47), p. 119.

${ }^{121}$ García Gallo, A., cit. (n. 108), p. 51.
} 


\section{BiBLIOGRAFÍA}

Arangio Ruiz, Vincenzo, Le genti e le città, en Ann. Messina (1913-1914).

Astolfi, Riccardo, Il matrimonio nel diritto romano preclásico (Pavia, Cedam, 2002). Bellomo Manlio, Per una storia del diritto privato medievale (Santiago de Compostela, Andavira editora, 2011).

Bonfante, Pietro, Corso di diritto romano, II: La proprietà, I (Milano, Giuffrè, 1966). Bonfante, Pietro, Forme primitive ed evoluzione della propietà romana. (Res mancipi e nec mancipi) (Roma, 1888-1889).

Capogrossi Luigi, s.v. "Patria potestà", en Enciclopedia del Diritto (Milano, Giuffrè, 1982), XXXII.

ChurrucA, Juan de, Egalité et inegalité des conjoints dans le mariage chrétien, en EL MISMO, Cristianismo y mundo romano (Bilbao, Ediciones de la Universidad de Deusto, 1988).

Daza MarTínez Jesús, "Portio debita" y comunidad familiar en cuanto claves interpretativas de una sintesis histórico-comparada en materias de liberalidades mortis causa, en IV Congreso Iberoamericano de derecho Romano, Ourense, 17-18 de Abril de 1998 (Vigo, Ediciones de la Universidad de Vigo, 1998), I.

De la Torre, Juan María, Literatura cristiana antigua, entornos y contenidos, I: "Desde su origen a la formación de la gran Iglesia” (Zamora, Monte Casino, 2003); V: Desde las postrimerías del Imperio romano de occidente hasta los albores de la oscura Edad Media (Zamora, Ediciones Monte Casino, 2009).

De Martino Francesco, s.v. "familia”, en Novissimo Digesto Italiano (Torino, 1981), IV.

FERnÁNDEZ De Buján Antonio, Derecho privado romano (4a edición, Madrid, Iustel, 2001).

Fustel de Coulanges, Numa Denis, La cité antique (Paris, 1903).

García de Valdeavellano, Luis, Estudios medievales del derecho privado (Sevilla, Universidad de Sevilla, 1977).

García Gallo, Alfonso, Manual de Historia del derecho español, I: El origen y la evolución del derecho (3a edición, Madrid, 1967)

GaUdemet, Jean, El matrimonio en Occidente (traducción al castellano, Madrid, Taurus, 1993)

López Barja de Quiroga, Pedro - Lomas Salmonte, Francisco Javier, Historia de Roma (Madrid, Akal, 2004).

MerÊA Paulo, O poder paternal na legislação visigótica, en Estúdios de direito visigótico (Coimbra, 1948).

Montanos Ferrín, Emma, La familia en la Alta Edad Media española (Pamplona, Ediciones de la Universidad de Navarra, 1980).

Otero Varela, Alfonso, La patria potestad en el derecho histórico español, en Estudios Histórico-Jurídicos (Madrid, 2005), II: Derecho privado.

Perozzi, Silvio, “Tollere liberum”, en Studii Simoncelli (Napoli, 1917).

Rodríguez DíEz José, Indisolubilidad y divorcio en la historia del matrimonio cristiano y canónico ¿Indisolubilidad relativa al futuro? en Anuario Jurídico y Económico Escurialense, 39 (2006).

Rodríguez Ennes Luis, Aproximación a la historia jurídica de Galicia (Santiago de Compostela, Xunta de Galicia, 1999).

RODRÍGUEZ ENNEs Luis, Bases jurídico-culturales de la institución adoptiva (monografías de la Universidad de Santiago de Compostela, 1978). 
RODRíguez ENNES, Luis, La adopción romana: continuidad y discontinuidad de un modelo, en Revista Dereito, 18 (2009) 1.

Schulz, Fritz, Principios del derecho romano (traducción al castellano, Madrid, Civitas, 2000).

Volterra Edoardo, s. v. "Famiglia (dir. rom)", en Enciclopedia del Diritto (Varese, Giuffré, 1967), XVI.

Volterra, Edoardo, Instituciones de derecho privado romano (traducción de J. Daza Martínez, Madrid, Civitas, 1988).

Volterra Edoardo, L'opera scientifica di Arangio Ruiz, en Archivio Giuridico, 170 (1966). 
